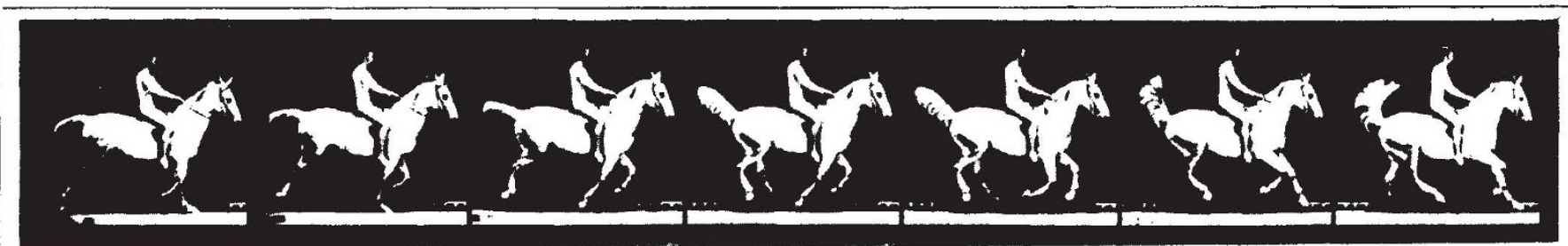

\section{Fast workers}

EADWEARD MuYbridge (he thought the Anglo Saxon version more striking than plain Edward Muggeridge) was a Victorian photographer who left Kingston-on-Thames in 1852 to sail for America. There he was run over by a stage coach and tried for the murder of his wife's lover. He was declared insane and acquitted after a former employee had testified: "He was most eccentric in his work; he would not take a picture unless the view suited him." On the credit side, he made a stereoscopic record of the Modoc Indian war and toured Central America (as Edwardo Santiago Muybridge), later selling collections of 120 prints at 100 dollars the set, which was a close call to skinning the market at 1876 exchange rates. More importantly, Muybridge made photographic studies of movement which laid the foundations of a completely new high speed photographic industry (not to mention a completely new movement in European art). In 1880 he became the first person to photograph movement (using "the famous zoopraxiscope camera") and resynthesise the movement on a screen. A strip from this original sequence (above) was featured in an exhibition accompanying the eleventh international congress on high speed photography at Imperial College, London. The same congress was marked by an exhibition of applied photography at the Royal Photographic Society, where the very latest achievements of the high speed photographic industry included the series reproduced below. It shows the development of a convective flow in the gas filling of an electric bulb as the current through the filament is switched on. The photographs are from eight threedimensional holographic images reconstructed from a sequence of double exposure holograms recorded on a single plate with a pulsed ruby laser. The pulse length was about $1 \mathrm{~ms}$ and the interval between pulses was 20 ms. The pictures were produced by the National Physical Laboratory, with whose permission they are reproduced. The Muybridge series appears by courtesy of the John Judkyn Memorial.

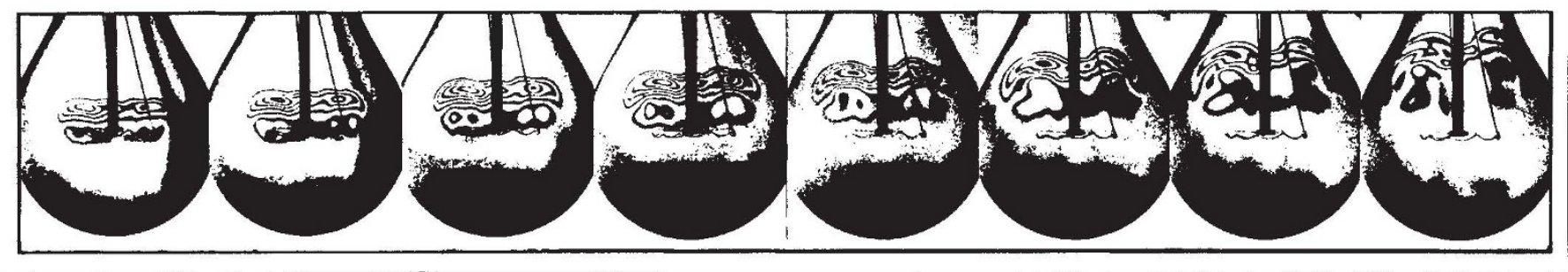

nuclear energy. But the powerful Joint Committee on Atomic Energy objected at such an intrusion on its patch, and the Science and Astronautics Committee eventually wound up with only non-nuclear energy research and development. But that is a distinct improvement over the present arrangement in which authority is split over a number of committees, and it also means that the new Science and Technology Committee will get jurisdiction over the non-nuclear programmes of the umbrella Energy Research and Development Administration.

The Bolling Committee had also recommended that the science committee be given "special oversight" over military R \& D, which would have given it authority to make studies and recommendations on the Pentagon's programmes, but it wouldn't have had the power to write laws in that area. But Edward Hébert, the 74-year-old chairman of the Armed Services Committee would have none of that, and his monopoly over the Defense Department programmes remains unbroken.

Finally, the Bolling proposals would have given the Science and Astronautics Committee jurisdiction over virtually all the programmes of the National Oceanic and Atmospheric Administration.

But Mrs Lenore Sullivan, Chairman of the Committee on Merchant Marine and Fisheries didn't relish the idea of her committee disappearing from under her, and the upshot is a grotesque split with some atmospheric programmes going to the new Science and Technology Committee, while oceanography stays with the Committee on Merchant Marine. But at least it was agreed during the floor debate last week that the two committees will work together on oceanic and atmospheric matters.

As for environmental research and development, both the Bolling Committee and the Democratic Caucus committee recommended that the new Science and Technology Committee would gain responsibility for that entire area, and so it will.

The upshot, then, is that many science and technology matters in the House will now be consolidated into one committee, which should make for smoother operations in some areas.
But it should be pointed out that the seniority system has survived completely untouched, and nobody had the temerity to alter the workings of perhaps the most powerful committee of all-the House Appropriations Committee, which deliberates on the budgets of the executive departments and agencies.

Bolling, at least, remains philosophical about the outcome of his attempts at reform. "It is a good start", he said last week, and indicated that he will try again next session.

Meanwhile, the Senate has for some time been making noises about taking a look at its own hopelessly confused committee structure, but so far has shown no signs of doing anything about it. It is far from clear at this stage, for example, which committees will get jurisdiction over the Energy Research and Development Administration, and science affairs are strung out over a whole range of Senate committees.

Since all bills must be approved by both the House and the Senate before they become law, the House reforms are clearly only half-way measures, no matter how good they are. 